\title{
Coordinated and Integrated Geomorphologic Analysis of Mass Transfers in Cold Climate Environments - The SEDIBUD (Sediment Budgets in Cold Environments) Programme
}

\author{
Achim A. Beylich \\ Additional information is available at the end of the chapter \\ http://dx.doi.org/10.5772/54725
}

\section{Introduction}

\section{General background}

Geomorphologic processes, responsible for transferring sediments and effecting landform change, are highly dependent on climate, and it is anticipated that climate change will have a major impact on the behaviour of Earth surface systems. Research on sedimentary fluxes from source to sink in a variety of different climatic environments is represented by a substantial body of literature. Studies on source-to-sink fluxes generally refer to the development of sediment budgets. A sediment budget is an accounting of the sources and disposition of sediment as it travels from its point of origin to its eventual exit from a defined landscape unit like a drainage basin, e.g. [1]. Accordingly, the development of a sediment budget necessitates the identification of processes of erosion, transport and deposition within a defined area, and their rates and controls $[1,2,3]$. The fundamental concept underpinning source-to-sink sediment flux and sediment budget studies is the basic sediment mass balance equation:

$\mathrm{I}=\mathrm{O}+-\Delta \mathrm{S}$

Where inputs $(\mathrm{I})$ equal outputs $(\mathrm{O})$ plus changes in net storage of sediment $(\Delta \mathrm{S})$. Source-tosink studies permit quantification of the transport and storage of sediment in a system. A thorough understanding of the current sediment production and flux regime within a system is fundamental to predict likely effects of changes to the system, whether climatic induced or human-influenced. Source-to-sink sediment flux and sediment budget research therefore enables the prediction of changes to erosion and sedimentation rates, knowledge of where 
sediment will be deposited, how long it will be stored and how much sediment will be remobilised $[1,3,4]$.

\section{Sediment sources}

Sediments are eroded and mobilised in source areas. Sediment sources are diverse and subject to variation in response to climate change. Global warming leads to the loss of glacial ice, which in turn increases slope instability caused by glacial de-buttressing, and flooding from glacial and moraine-dammed lakes $[5,6]$. All these processes redistribute sediments and operate at different rates as a result of change to the system. Glaciers and ice sheets exert strong controls on the supply of sediments. For example, Knight et al. [7] identify the basal ice layer of a section of the Greenland ice sheet as the dominant source of sediment production. There is, however, only limited knowledge of debris fluxes from ice sheets and glaciers and its variability. The main mechanisms of sediment production in source areas can be described in terms of contemporary environmental conditions. However, in order to fully understand sediment supply a longer-term perspective is needed. Over the Quaternary, glacier fluctuations have had profound influences in depositing extensive mantles of sediments. More-widely, periglacial activity has altered the landscape under non-glacial cold climate conditions. The obvious imprint of this legacy is often reflected in contemporary sediment transfer rates where preexisting deposits are eroded by present-day processes $[6,8]$.

\section{Sediment transfers}

Sediment transfers move eroded sediments from their source area to an area of temporal storage or long-term deposition in sinks. Rates of sediment transfer are not only conditioned by competence of geomorphic processes but also by the availability of sediment for transport. Accordingly, in assessing sediment transfer we need to quantify the forces, which drive transport processes but equally account for the factors, which control sediment supply [8]. Glacial fluxes are arguably the most significant processes for contemporary sediment flux [9]. Small-scale process studies very often focus on sedimentary fluxes from areas of weathering and erosion to areas of storage within defined landscape units like drainage basins, whereas large-scale sediment systems couple headwaters to oceanic sinks. For example, Gordeev [10], applying models developed by Morehead et al. [11], estimates the increase in sediment load in Arctic rivers in response to a rise in surface temperature of the drainage basins. Based on this model, increases in river discharge lead to an increase in the sediment flux of the six largest Arctic rivers, predicted to range from $30 \%$ to $122 \%$ by the year 2100 .

\section{Sediment stores / sinks}

The identification of storage elements and sinks is critical to the effective study and understanding of source-to-sink sedimentary fluxes [1]. The setting of a particular drainage basin defines the boundary conditions for storage within that landscape unit. Within a defined landscape unit like a drainage basin, the slope and valley infill elements constitute the key storage units and storage volumes are important for addressing time-dependent sediment budget dynamics. Dating of storage in sedimentary source-to-sink flux studies is applied to determine or estimate the ages and chronology of the storage components within the system. An understanding of the nature of primary stores, secondary stores and the potential storage capacities of different types of drainage basins is important along with knowledge of sediment 
residence times. Of growing importance is the development of innovative field methods, such as geophysical techniques for estimating sediment storage volumes [12, 13, 14]. Within largescale sediment systems oceanic sinks are most important and provide the opportunity to estimate rates of sediment production and delivery at long-term temporal as well as continental spatial scales $[15,16]$.

\section{The I.A.G. / A.I.G. SEDIBUD programme}

Amplified climate change and ecological sensitivity of polar and cold environments has been highlighted as a key global environmental issue [17]. Projected climate change in cold regions is expected to alter melt season duration and intensity, along with the number of extreme rainfall events, total annual precipitation and the balance between snowfall and rainfall. Similarly, changes to the thermal balance are expected to reduce the extent of permafrost and seasonal ground frost and increase active layer and thaw depths. These effects will undoubtedly change surface environments in cold environments and alter the fluxes of sediments, nutrients and solutes, but the absence of data and analysis to understand the sensitivity of the surface environment are acute in cold climate environments.

The SEDIBUD (Sediment Budgets in Cold Environments) Programme of the International Association of Geomorphologists (I.A.G./A.I.G.) was formed in 2005 to address this identified key knowledge gap $[18,19]$. SEDIBUD currently has about 400 members worldwide and the Steering Committee of this international programme is composed of ten scientists from eight different countries:

- Achim A. Beylich (Chair) (Norway)

- Armelle Decaulne (Secretary) (France)

- John C. Dixon (USA)

- Scott F. Lamoureux (Vice-Chair) (Canada)

- John F. Orwin (Canada)

- Jan-Christoph Otto (Austria)

- Irina Overeem (USA)

- Porsteinn Sæmundsson (Iceland)

- Jeff Warburton (UK)

- Zbigniew Zwolinski (Poland)

The central research question of this global group of scientists is to 
Initially formed as European Science Foundation (ESF) Network SEDIFLUX (2004-2006) [20, 21], SEDIBUD has further expanded to a global group of researchers with in total 44 field research sites (SEDIBUD Key Test Sites) located in polar and alpine regions in the northern and southern hemisphere, see [22]. Research carried out at each site varies by programme, logistics and available resources, but typically represents interdisciplinary collaborations of geomorphologists, hydrologists, ecologists, permafrost scientists and glaciologists. SEDIBUD has developed a key set of primary surface process monitoring and research data requirements to incorporate results from these diverse projects and allow coordinated quantitative analysis across the programme. SEDIBUD Key Test Sites provide data on annual climate conditions, total discharge and particulate and dissolved fluxes as well as information on other relevant surface processes. A number of selected SEDIBUD Key Test Sites is providing high-resolution data on climate conditions, runoff and sedimentary fluxes, which in addition to the annual data contribute to the SEDIBUD Metadata Database which is currently developed. To support these coordinated efforts, the SEDIFLUX Manual [3] has been produced to establish common methods and data standards $[18,19]$. In addition, a framework paper for characterizing fluvial sediment fluxes from source to sink in cold environments has been published by the group [23].

Comparable datasets from different SEDIBUD Key Test Sites are analysed to address key research questions of the SEDIBUD Programme as defined in the SEDIBUD Working Group Objective [24].

\section{Compiled annual data from defined SEDIBUD key test sites}

Table 1 compiles key parameters of four selected SEDIBUD research field sites (Figures 1 and 2) as examples.

\begin{tabular}{|c|c|c|c|c|c|c|}
\hline $\begin{array}{l}\text { SEDIBUD Key } \\
\text { Test Site } \\
\text { Catchment }\end{array}$ & $\begin{array}{l}\text { Geographical } \\
\text { coordinates }\end{array}$ & $\begin{array}{l}\text { Area } \\
\left(\mathrm{km}^{2}\right)\end{array}$ & $\begin{array}{l}\text { Elevation range }(\mathrm{m}) \text {; } \\
\text { Topographic relief } \\
\text { (m) }\end{array}$ & $\begin{array}{l}\text { Mean annual } \\
\text { air temperature } \\
\text { in }{ }^{\circ} \mathrm{C}\end{array}$ & $\begin{array}{l}\text { Annual } \\
\text { eprecipitation } \\
(\mathrm{mm})\end{array}$ & Lithology \\
\hline $\begin{array}{l}\text { Hrafndalur } \\
\text { (Iceland) }\end{array}$ & $\begin{array}{l}65^{\circ} 28^{\prime} \mathrm{N}, \\
13^{\circ} 42^{\prime} \mathrm{W}\end{array}$ & 7 & $\begin{array}{l}6-731 \\
725\end{array}$ & 3.6 & 1719 & Rhyolites \\
\hline $\begin{array}{l}\text { Austdalur } \\
\text { (Iceland) }\end{array}$ & $\begin{array}{l}65^{\circ} 16^{\prime} \mathrm{N}, \\
13^{\circ} 48^{\prime} \mathrm{W}\end{array}$ & 23 & $\begin{array}{l}0-1028 \\
1028\end{array}$ & 3.6 & 1431 & Basalt \\
\hline $\begin{array}{l}\text { Latnjavagge } \\
\text { (Sweden) }\end{array}$ & $\begin{array}{l}68^{\circ} 20^{\prime} \mathrm{N}, \\
18^{\circ} 30 \mathrm{E}\end{array}$ & 9 & $\begin{array}{l}950-1440 \\
490\end{array}$ & -2.0 & 852 & $\begin{array}{l}\text { Mica-garnet } \\
\text { schists }\end{array}$ \\
\hline $\begin{array}{l}\text { Kidisjoki } \\
\text { (Finland) }\end{array}$ & $\begin{array}{l}69^{\circ} 47^{`} \mathrm{~N} \\
27^{\circ} 05^{`} \mathrm{E}\end{array}$ & 18 & $\begin{array}{l}75-365 \\
290\end{array}$ & -2.0 & 415 & $\begin{array}{l}\text { Gneisses and } \\
\text { granulites }\end{array}$ \\
\hline
\end{tabular}

Table 1. Key parameters of four selected catchment geo-systems (SEDIBUD Key Test Sites) in Eastern Iceland, Swedish Lapland and Finnish Lapland. 


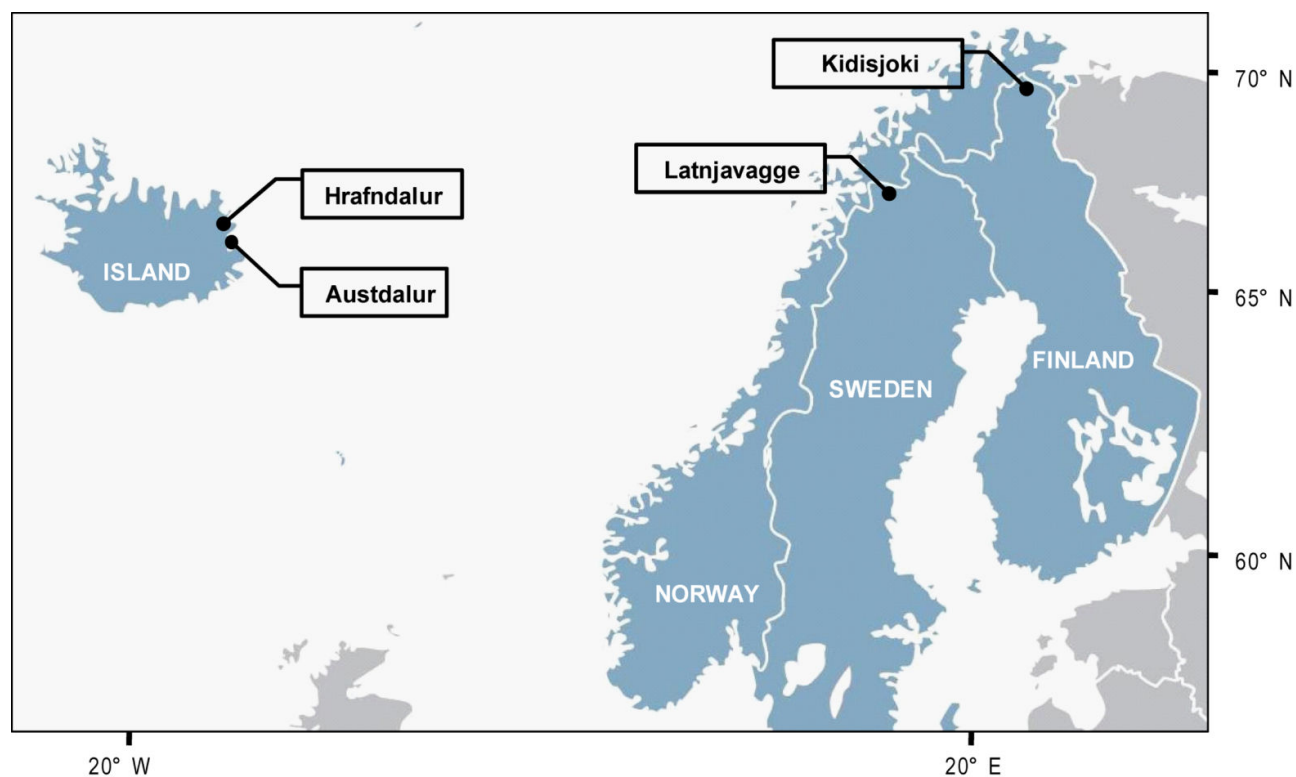

Figure 1. Location of the four selected SEDIBUD Key Test Sites Hrafndalur (Iceland), Austdalur (Iceland), Latnjavagge (Sweden) and Kidisjoki (Finland)

The generation and compilation of directly comparable data sets from the defined SEDIBUD Key Test Sites in the SEDIBUD Metadata Database is the basis for modelling effects of climate change on sedimentary fluxes and yields in cold climate environments by using space-for-time substitution [3, 18-21].

Annual data (as required from defined SEDIBUD Key Test Sites) from the four examples Hrafndalur (Iceland) [25, 26, 27], Austdalur (Iceland) [26, 27], Latnjavagge (Sweden) [25, 26, $28]$ and Kidisjoki (Finland) $[25,26]$ are compiled in Table 2. Time series of these mean annual data are published in [25-28].

\section{Direct comparison and major controls of annual mass transfers within the four selected catchment geo-systems}

On the basis of geomorphic process rates which were calculated for the Hrafndalur, Austdalur, Latnjavagge and Kidisjoki drainage basins after longer-term field studies (several years of process monitoring, mapping and observation) [26], the absolute and the relative importance of present-day denudative surface processes in the entire catchments was estimated by the quantification of the mass transfers caused by the different denudative surface processes. To allow direct comparison of the different denudative processes, all mass transfers are shown as tonnes multiplied by meter per year $\left(\mathrm{t} \mathrm{m} \mathrm{yr}^{-1}\right)$, i.e. as the product of the annually transferred mass and the corresponding transport distance, see [26, 29-31]. 


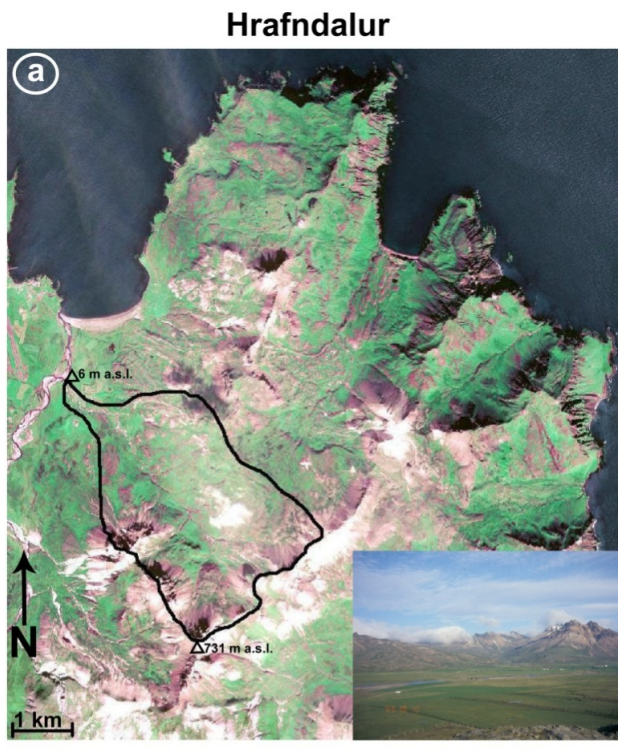

Source: Inniheldur efni $\odot$ CNES 2002 - 2007, Distribution Spot Image S.A. France, öll réttindi áskilin / @ Landmælingar Íslands 2011

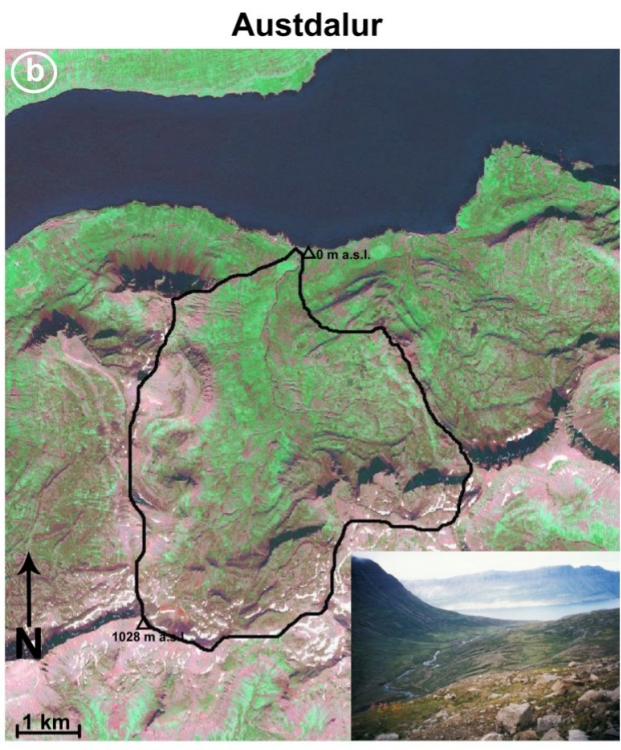

Source: Inniheldur efni ๔ CNES 2002 - 2007, Distribution Spot Image S.A France, öll réttindi áskilin / @ Landmælingar İslands 2011

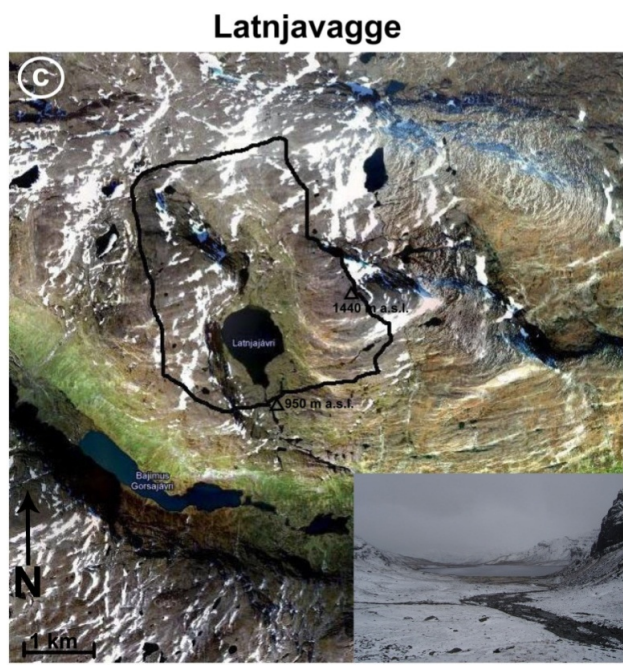

Source: ๑ 2011 Google - Grafiken (๑) 2011 TerraMetrics, Kartendaten (๑) 2011 Tele Atlas

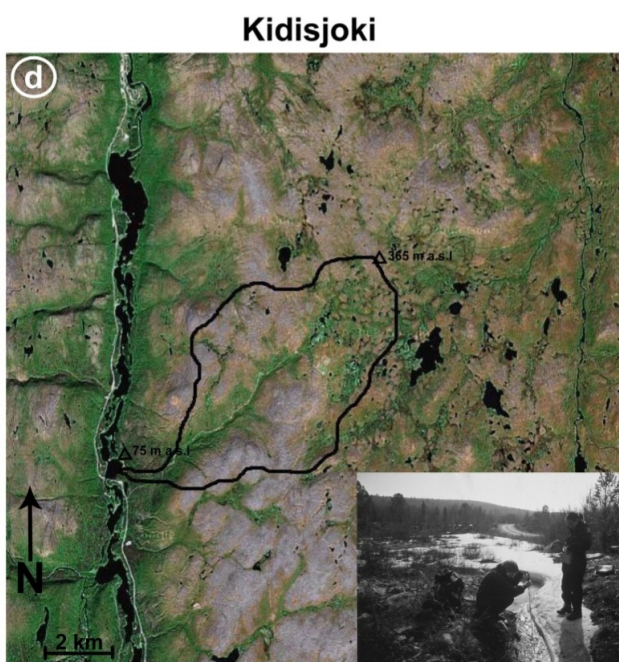

Source: @ 2011 Google - Grafiken (๑ 2011 TerraMetrics, Kartendaten (๑ 2011 Tele Atlas

Figure 2. Views of the four selected SEDIBUD Key Test Sites Hrafndalur (Eastern Iceland), Austdalur (Eastern Iceland), Latnjavagge (Swedish Lapland) and Kidisjoki (Finnish Lapland) 


\begin{tabular}{|c|c|}
\hline $\begin{array}{l}\text { Name of SEDIBUD Key Test Site: } \\
\text { Hrafndalur (Iceland) }\end{array}$ & $\begin{array}{l}\text { Period of investigations (years): } 2002 \text { - } 2010 \\
\text { (Hydrological Year (HY) or Calender Year (CY); }\end{array}$ \\
\hline Principal Investigator: Achim A. Beylich & Published Data (PD) or Unpublished Data (UPD)) \\
\hline Mean annual temperature $\left({ }^{\circ} \mathrm{C}\right)$ : & 3.6 \\
\hline Total annual precipitation [mm]: & 1719 \\
\hline Total annual runoff [mm]: & 1344 \\
\hline Annual suspended sediment yield $\left[\mathrm{t} \mathrm{km}^{-2}\right]$ : & 19 \\
\hline Annual solute yield (atmospherically corrected) [ $\left.\mathrm{t} \mathrm{km}^{-2}\right]$ : & 29 \\
\hline Name of SEDIBUD Key Test Site: & Period of investigations (years): 1996 - 2010 \\
\hline Austdalur (Iceland) & (Hydrological Year (HY) or Calender Year (CY); \\
\hline Principal Investigator: Achim A. Beylich & Published Data (PD) or Unpublished Data (UPD)) \\
\hline Mean annual temperature $\left({ }^{\circ} \mathrm{C}\right)$ : & 3.6 \\
\hline Total annual precipitation [mm]: & 1431 \\
\hline Total annual runoff $[\mathrm{mm}]$ : & 1130 \\
\hline Annual suspended sediment yield [ $\left.\mathrm{t} \mathrm{km}^{-2}\right]$ : & 42 \\
\hline Annual solute yield (atmospherically corrected) [ $\left.\mathrm{t} \mathrm{km}^{-2}\right]$ : & 8 \\
\hline Name of SEDIBUD Key Test Site: & Period of investigations (years): 2000 - 2010 \\
\hline Latnjavagge (Sweden) & (Hydrological Year (HY) or Calender Year (CY); \\
\hline Principal Investigator: Achim A. Beylich & Published Data (PD) or Unpublished Data (UPD)) \\
\hline Mean annual temperature $\left({ }^{\circ} \mathrm{C}\right)$ : & -2.0 \\
\hline Total annual precipitation [mm]: & 852 \\
\hline Total annual runoff [mm]: & 717 \\
\hline Annual suspended sediment yield [t km-2]: & 2.4 \\
\hline Annual solute yield (atmospherically corrected) [ $\left.\mathrm{km}^{-2}\right]$ : & 4.9 \\
\hline Name of SEDIBUD Key Test Site: & Period of investigations (years): 2002 - 2010 \\
\hline Kidisjoki (Finland) & (Hydrological Year (HY) or Calender Year (CY); \\
\hline Principal Investigator: Achim A. Beylich & Published Data (PD) or Unpublished Data (UPD)) \\
\hline Mean annual temperature $\left({ }^{\circ} \mathrm{C}\right)$ : & -2.0 \\
\hline Total annual precipitation [mm]: & 415 \\
\hline Total annual runoff [mm]: & 324 \\
\hline Annual suspended sediment yield [ $\left.\mathrm{km}^{-2}\right]$ : & 0.3 \\
\hline Annual solute yield (atmospherically corrected) [t km-2]: & 3.1 \\
\hline
\end{tabular}

Table 2. Compiled annual data from four selected SEDIBUD Key Test Sites 
As based on these quantitative investigations, in all selected study areas in sub-Arctic oceanic eastern Iceland, Arctic oceanic Swedish Lapland and sub-Arctic oceanic Finnish Lapland the intensity of contemporary denudative surface processes and mass transfers caused by these geomorphic processes is altogether rather low.

A direct comparison of the annual mass transfers within the four investigated drainage basins (Figure 3) summarises that there are differences between process intensities and the relative importance of different denudative processes within the study areas in Eastern Iceland, Swedish Lapland and Finnish Lapland.

The major controls of the detected differences are (see Figure 3):

i.

Hydro-climate and connected runoff:

The higher annual precipitation along with the larger number of extreme rainfall events and the higher frequency of snowmelt and rainfall generated peak runoff events in eastern Iceland as compared to Swedish Lapland and Finnish Lapland leads to higher mass transfers (Figure 3). All four study areas are located in oceanic cold regions and projected climate change is expected to alter melt season duration and intensity, along with an increased number of extreme rainfall events, total annual precipitation and the balance between snowfall and rainfall. In addition, changes in the thermal balance are expected to reduce the extent of permafrost and seasonal ground frost and increase active layer depths [17]. Looking at the existing differences between Hrafndalur / Austdalur (eastern Iceland), Latnjavagge (Swedish Lapland) and Kidisjoki (Finnish Lapland) it seems obvious that the projected changes in climate will cause significant changes of mass transfers.
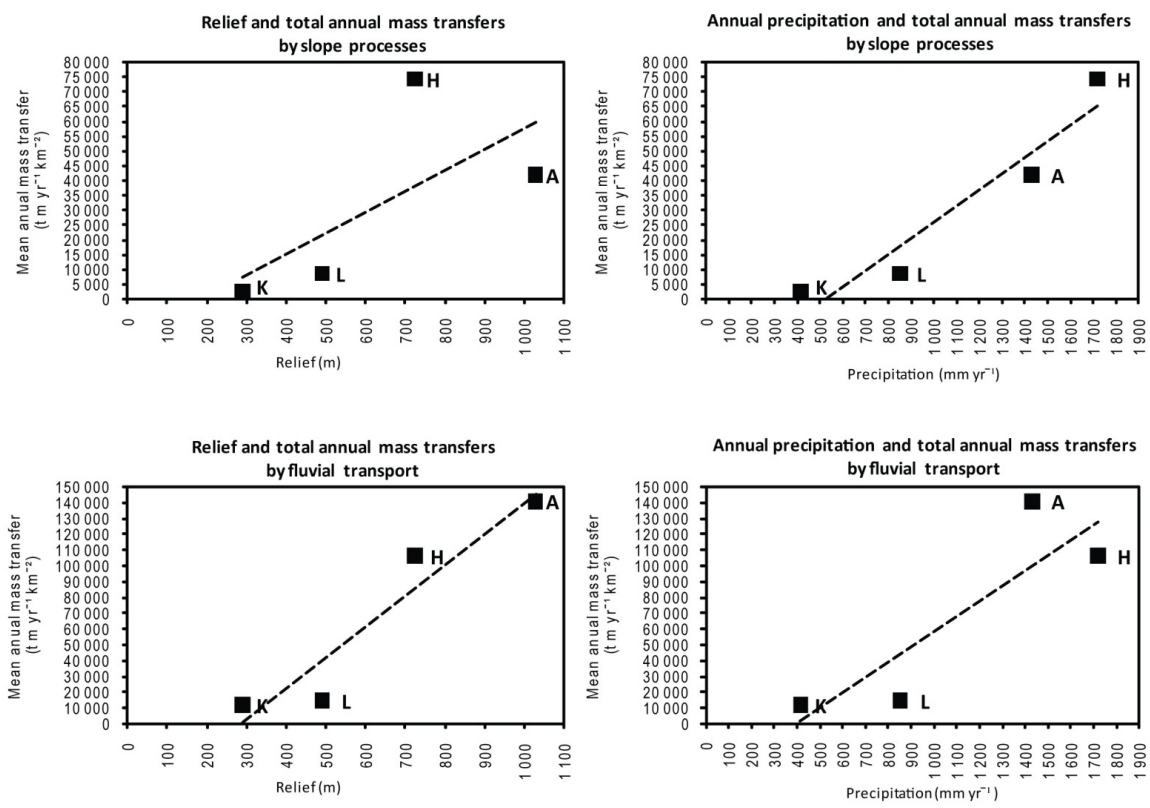

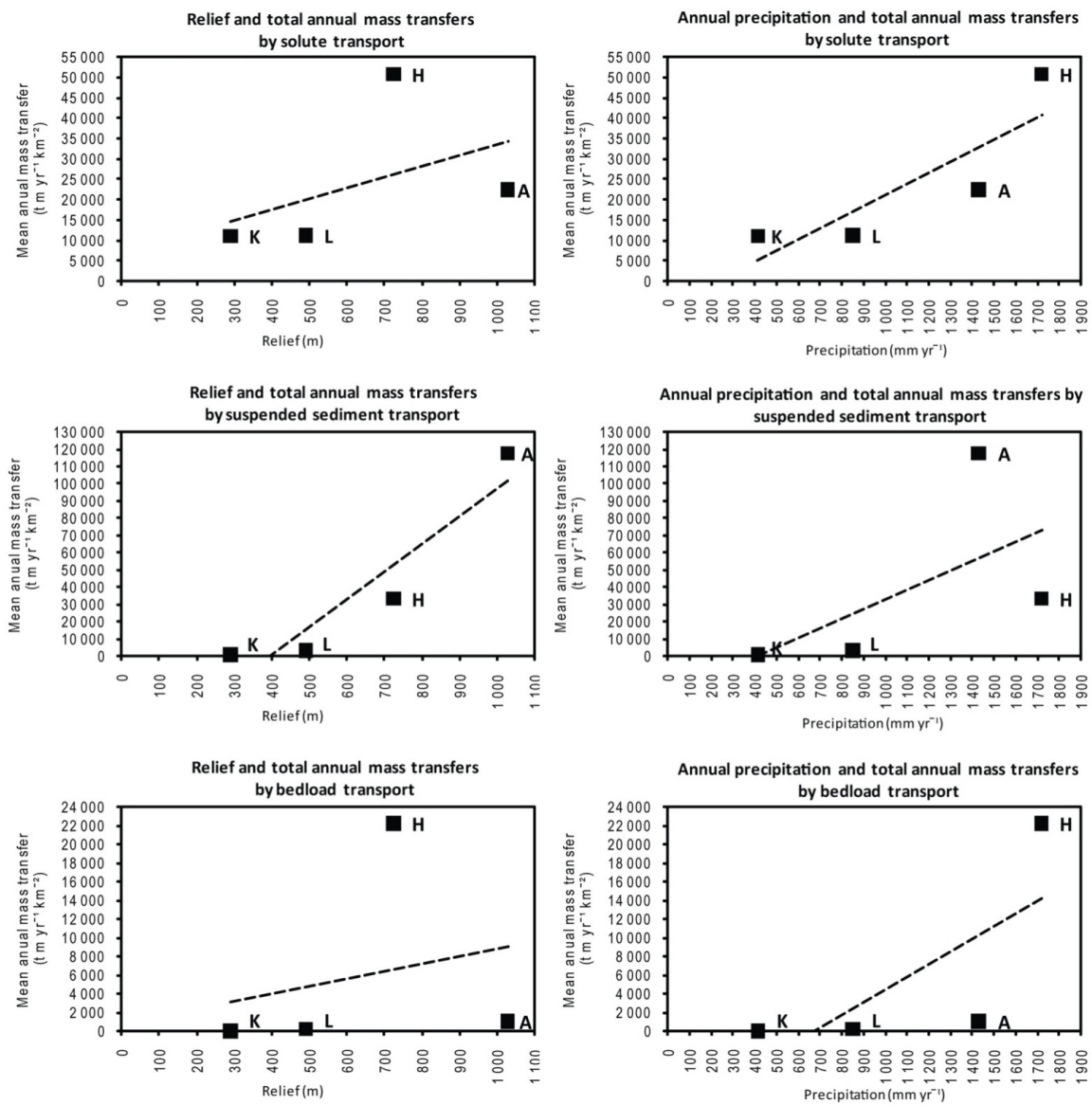

Figure 3. Statistical correlations between topographic relief and annual precipitation and annual mass transfers by slope processes and fluvial transport (fluvial solute transport, fluvial suspended sediment transport, fluvial bedload transport) for the four selected SEDIBUD Key Test Sites Hrafndalur (H), Austdalur (A), Latnjavagge (L) and Kidisjoki (K)

\section{ii. Topographic relief:}

The greater steepness of the Icelandic drainage basins leads to larger mass transfers here as compared to Latnjavagge and especially to Kidisjoki (Figure 3).

iii. Lithology:

The low resistance of the rhyolites in Hrafndalur causes especially high weathering rates and connected mass transfers in this drainage basin (see Figure 3). Due to the lower resistance of the rhyolites as compared to the basalts found in Austdalur Postglacial modification of the glacially formed relief is clearly further advanced in Hrafndalur as compared to Austdalur. 
iv. Vegetation cover (with vegetation cover being partly modified by human activity):

The significant disturbance of the vegetation cover by direct human impacts in Hrafndalur / Austdalur (eastern Iceland) causes higher mass transfers by slope wash here whereas restricted sediment availability is a major reason for lower mass transfers in Latnjavagge (Swedish Lapland) and Kidisjoki (Finnish Lapland).

\section{Conclusions}

As a result, hydro-climate and topographic relief, followed by lithology and vegetation cover (with vegetation cover being partly modified by human activity), are the main controls of the mass transfers modifying the investigated sub-Arctic / Arctic landscapes, see also [32]. More studies to the present one, carried out within the SEDIBUD Programme with unified geomorphologic field methods [3, 21, 33, 34] in environments having different climatic, vegetation, human impact, topographic, lithological / geological and/or tectonic features will help to gain improved understanding of the internal differentiation of different global cold climate environments, see e.g. [21, 33, 35, 36]. Furthermore, additional information on the control mechanisms of processes, the role of extreme geomorphic events for longer-term mass transfers and sediment budgets, the general intensity of geomorphic processes and mass transfers, and the relative importance of different processes for slope and valley formation and relief development under different environmental conditions can be collected. Direct comparisons of SEDIBUD Key Test Sites (catchment geo-systems) and the application of the Ergodic principle of space-for-time substitution will improve the possibilities to model relief development as well as possible effects of projected climate change in cold climate environments.

\section{Acknowledgements}

The author would like to thank the SEDIBUD Steering Committee Members and numerous SEDIBUD Members for fruitful discussions and numerous valuable inputs.

\section{Author details}

Achim A. Beylich

Address all correspondence to: achim.beylich@ngu.no

Geological Survey of Norway (NGU), Geo-Environment Division, Trondheim, Norway 


\section{References}

[1] Reid L.M., Dunne T. Rapid evaluation of sediment budgets. Catena 1996.

[2] Slaymaker O. Research developments in the hydrological sciences in Canada (1995-1998): Surface water - quantity, quality and ecology. Hydrological Processes 2000; 14 1539-1550.

[3] Beylich A.A., Warburton, J. editors. Analysis of source-to-sink fluxes and sediment budgets in changing high-latitude and high-altitude cold environments. SEDIFLUX Manual. NGU Report 2007.053.

[4] Gurnell A.M., Clark M.J. editors. Glacio-fluvial sediment transfer: An Alpine perspective. Chichester: Wiley; 1987.

[5] Evans S.G., Clague J.J. Recent climate change and catastrophic geomorphic processes in mountain environments. Geomorphology 1994; 10 107-128.

[6] Ballantyne C.K. Paraglacial geomorphology. Quaternary Science Reviews 2002; 21 1935-2017.

[7] Knight P.G., Waller R.I., Patterson C.J., Jones A.P., Robinson Z.P. Discharge of debris from ice at the margin of the Greenland ice sheet. Journal of Glaciology 2002; 48 192-198.

[8] Warburton J. Sediment budgets and rates of sediment transfer across cold environments in Europe: a commentary. Geografiska Annaler 2007; 89A(1) 95-100.

[9] Harbor J., Warburton J. Glaciation and denudation rates. Nature 1992; 356751.

[10] Gordeev V.V. Fluvial sediment flux to the Arctic Ocean. Geomorphology 2006; 80 94-104.

[11] Morehead M.D., Syvitski J.P., Hutton E.W., Peckham S.D. Modeling the temporal variability in the flux of sediment from ungauged river basins. Global and Planetary Change 2003; 39 95-110.

[12] Schrott L., Hufschmidt G., Hankammer M., Hoffmann T., Dikau R. Spatial distribution of sediment storage types and quantification of valley fill deposits in an alpine basin, Reintal, Bavarian Alps, Germany. Geomorphology 2003; 55 45-63.

[13] Sass O. Spatial patterns of rockfall intensity in the northern Alps. Zeitschrift für Geomorphologie N.F. 2005; Suppl. 138 51-65.

[14] Hansen L., Beylich A.A., Burki V., Eilertsen R., Fredin O., Larsen E., Lyså A., Nesje A., Stalsberg K., Tønnesen J.-F. Stratigraphic architecture and infill history of a deglaciated bedrock valley based on georadar, seismic profiling and drilling. Sedimentology 2009; 56 1751-1773. 
[15] Rise L., Ottesen D., Berg K., Lundin E. Large-scale development of the mid-Norwegian margin during the last 3 million years. Marine and Petroleum Geology 2005; 22 33-44.

[16] Dowdeswell J.A., Ottesen D., Rise L. Flow switching and large-scale deposition by ice streams draining former ice sheets. Geology 2006; 34 313-316.

[17] ACIA, Impacts of a warming Arctic: Arctic Climate Impact Assessment. ACIA Overview Report. Cambridge University Press; 2004.

[18] Beylich A.A. Quantitative studies on sediment fluxes and sediment budgets in changing cold environments - potential and expected benefit of coordinated data exchange and the unification of methods. Landform Analysis 2007; 5 9-10.

[19] Beylich A.A., Lamoureux S.F., Decaulne A. Coordinated quantitative studies on sediment fluxes and sediment budgets in changing cold environments examples from three SEDIBUD key test sites in Canada, Iceland and Norway. Landform Analysis 2007; 5 11-12.

[20] Beylich A.A., Etienne S., Etzelmüller B., Gordeev V.V., Käyhkö J., Rachold V., Russell A.J., Schmidt K.-H., Sæmundsson Th., Tweed F.S., Warburton J. Sedimentary Sourceto-Sink-Fluxes in Cold Environments - Information on the European Science Foundation (ESF) Network SEDIFLUX. Zeitschrift für Geomorphologie N.F. 2005; Suppl. 138 229-234.

[21] Beylich A.A., Etienne S., Etzelmüller B., Gordeev V.V., Käyhkö J., Rachold V., Russell A.J., Schmidt K.-H., Sæmundsson Th., Tweed F.S., Warburton J. The European Science Foundation (ESF) Network SEDIFLUX - An introduction and overview. Geomorphology 2006; 80(1-2) 3-7.

[22] Beylich A.A., Decaulne A., Dixon J.C., Lamoureux S.F., Orwin J.F., Otto J.-Ch., Overeem I., Sæmundsson Th., Warburton J., Zwolinski Z. The global Sediment Budgets in Cold Environments (SEDIBUD) Programme: Coordinated studies of sedimentary fluxes and budgets in changing cold environments. Zeitschrift für Geomorphologie 2012; 56(1) 3-8.

[23] Orwin J.F., Lamoureux S.F., Warburton J., Beylich A.A. A framework for characterizing fluvial sediment fluxes from source to sink in cold environments. Geografiska Annaler 2010; 92A(2) 155-176.

[24] International association of Geomorphologists (I.A.G. / A.I.G.): SEDIBUD Website. http://www.geomorph.org/wg/wgsb.html (accessed 9 June 2012).

[25] Beylich A.A. Chemical and mechanical fluvial denudation in cold environments Comparison of denudation rates from three catchments in sub-Arctic Eastern Iceland, sub-Arctic Finnish Lapland and Arctic Swedish Lapland. Jökull 2009; 59 19-32.

[26] Beylich A.A. Mass transfers, sediment budgets and relief development in cold environments: Results of long-term geomorphologic drainage basin studies in Iceland, 
Swedish Lapland and Finnish Lapland. Zeitschrift für Geomorphologie 2011; 55(2) 145-174.

[27] Beylich A.A., Kneisel Ch. Sediment budget and relief development in Hrafndalur, sub-Arctic oceanic Eastern Iceland. Arctic, Antarctic and Alpine Research 2009; 41(1) 3-17.

[28] Beylich A.A., Mass transfers, sediment budget and relief development in the Latnjavagge catchment, Arctic oceanic Swedish Lapland. Zeitschrift für Geomorphologie N.F. 2008; 52(1) 149-197.

[29] Jäckli H. Gegenwartsgeologie des Bündnerischen Rheingebietes. Beitrag zur Geologischen Karte der Schweiz. Geotechnische Serie 1957; 36.

[30] Rapp A. Recent development of mountain slopes in Kärkevagge and surroundings, Northern Scandinavia. Geografiska Annaler 1960; 42 71-200.

[31] Barsch D. Studien zur gegenwärtigen Geomorphodynamik im Bereich der Oobloyah Bay, N-Ellesmere Island, N.W.T., Kanada. Heidelberger Geographische Arbeiten $1981 ; 69$ 123-161.

[32] Slaymaker O., Spencer T., Dadson S. Landscape and landscape-scale processes as the unfilled niche in the global environmental change debate: an introduction. In: Slaymaker O., Spencer T., Embleton-Hamann C. (eds.) Geomorphology and Global Environmental Change. Cambridge University Press; 2009. p1-36.

[33] Beylich A.A., Lamoureux S.F., Decaulne A. The global I.A.G./A.I.G. SEDIBUD (Sediment Budgets in Cold Environments) programme: Introduction and overview. Norwegian Journal of Geography 2008; 62(2) 50-51.

[34] Beylich A.A., Lamoureux S.F., Decaulne A. Developing frameworks for studies on sedimentary fluxes and budgets in changing cold environments. Quaestiones Geographicae 2011; 30(1) 5-18.

[35] Barsch D. Geomorphologische Untersuchungen zum periglazialen Milieu polarer Geosysteme. Zeitschrift für Geomorphologie N.F. 1984; Suppl. 50 107-116.

[36] Barsch D. Forschungen in Polargebieten. Heidelberger Geowissenschaftliche Abhandlungen 1986; $633-50$. 
